\title{
Phosphorus Fertilizer Effects on Haricot Bean (Phaseolus vulgaris L.) Varieties on Andisols of Sidama, Ethiopia
}

\author{
Melkamu Hordofa Sigaye ${ }^{1,}$, Kidist Kebede $^{1}$, Ribka Mekuria $^{1}$, Belstie Lulie ${ }^{2}$, Ashenafi Nigussei $^{1}$ \\ ${ }^{1}$ Ethiopian Institute of Agricultural Research Institute, Wondo Genet Agri. Research Center, Shashemane, Ethiopia \\ ${ }^{2}$ Ethiopian Institute of Agricultural Research Institute, Debre Markos Agri. Research Center, Debre Markos, Ethiopia
}

Email address:

hordofa.mel@gmail.com (M. H. Sigaye)

${ }^{*}$ Corresponding author

\section{To cite this article:}

Melkamu Hordofa Sigaye, Kidist Kebede, Ribka Mekuria, Belstie Lulie, Ashenafi Nigussei. Phosphorus Fertilizer Effects on Haricot Bean (Phaseolus vulgaris L.) Varieties on Andisols of Sidama, Ethiopia. American Journal of Plant Biology. Vol. 5, No. 4, 2020 , pp. 82-87. doi: 10.11648/j.ajpb.20200504.12

Received: August 18, 2020; Accepted: September 23, 2020; Published: November 23, 2020

\begin{abstract}
Phosphorus is the most important essential mineral nutrient which commonly restricts the growth and development of crops, associated with early maturity of crops, and for adequate grain production, energy transfer, photosynthesis, and nitrogen fixation. Field experiment was conducted during 2018-2020 at, Sidama Ethiopia to determine the yield response of haricot bean varieties to phosphorus fertilizer application. The treatment consisted of three haricot bean varieties (Hawassadume, Ibbado and Nasir) and five phosphorus levels $\left(0,10,20,30\right.$ and $\left.40 \mathrm{~kg} \mathrm{Pha}^{-1}\right)$ and laid out in randomized complete block design in factorial combination with three replications. The study result revealed that the maximum grain yield of Hawassa dume $\left(25.6 \mathrm{tha}^{-1}\right)$, Ibbado $\left(22.4 \mathrm{t} \mathrm{ha}^{-1}\right)$ and Nasir $\left(21.1 \mathrm{t} \mathrm{ha}^{-1}\right)$ were obtained from application of $40 \mathrm{~kg} \mathrm{P} \mathrm{ha}^{-1}$. Hawassa dume variety showed the best performance in all parameters followed by Nasir where and Ibado showed the least except in 1000 seed weight. The result of economic analysis revealed that all treatments were economically feasible as the net benefit values were greater than zero $(\mathrm{NBV}>0)$. Likewise, Hawassa dume was found to be the most productive cultivar for economical production in the study areas. Thus, based on the result obtained, it was possible to conclude that phosphorus fertilizer rate of $40 \mathrm{~kg} \mathrm{P} \mathrm{ha}^{-1}$ was promising to enhance yield of haricot bean at Sidama, Ethiopia and similar areas which have the same soil property.
\end{abstract}

Keywords: Grain Yield, Haricot Bean, Phosphorus

\section{Introduction}

Haricot bean (Phaseolus vulgaris L) is an important pulse crop in Ethiopia, and occupying about $366,877 \mathrm{t} \mathrm{ha}^{-1}$ and $19.69 \%$ of land area allocated to pulses and producing about 463,008 tons of grain $16.83 \%$ of the total pulses production [1]. The average yield $1.26 \mathrm{t} \mathrm{ha}^{-1}$ of common bean is low which is because phosphorus is deficient in about $70 \%$ of soils of Ethiopia [2].

Phosphorus is an essential mineral nutrient most commonly restricted the growth of crops and is an essential element required for plant growth and also associated with early maturity of crops and development particularly for adequate grain production [3]. Phosphorus contributes to the biomass construction of micronutrients, the metabolic process of energy transfer, signal transduction, macromolecular biosynthesis, photosynthesis and respiration chain reactions and nitrogen $(\mathrm{N})$ fixation $[4,5]$. Similarly, Halvorson and Black, [6] reported that Phosphorus need to be available to the crop in balanced proportions to optimize crop yield and quality and efficiency of crop production.

Some of researchers studied the adequate rates of phosphorus on yield and yield components of bean. Barbosa and Silva, [7] reported that maximal economic fertilizer level for bean production was equal to $47 \mathrm{~kg} \mathrm{ha}^{-1}$. Singh et al. [8] indicated the maximum dry matter yield was attained at the 40 $\mathrm{mg} \mathrm{P} \mathrm{kg}{ }^{-1}$ application rate. Gidago et al. [9] indicated that seed yield and total biomass was significantly influenced by $\mathrm{P}$ application and the maximum values of these traits were obtained at the rate of $40 \mathrm{~kg} \mathrm{P} \mathrm{ha}^{-1}$. Fageria and De Carvalho [10] showed phosphorus application significantly increased 
dry matter, grain yield and yield components, but the response varied from soil to soil and the critical extractable $\mathrm{P}$ level varied from 5.4 to $86 \mathrm{mg} \mathrm{P} \mathrm{kg}^{-1}$ of soil depending on the soil.

Large areas of agricultural land are poor in phosphorus, because the soil of these areas has a phosphate deficiency [11]. Andisols are characterized by a high phosphorus (P) fixation capacity, which is a limiting factor for plant production. The low yield is contributed from andic soils which reduce availability of $\mathrm{P}$ and basic cations as $\mathrm{Ca}$ and $\mathrm{Mg}$, and affect activities of soil microorganisms [4]. Recently, according to the soil fertility map Ethiopia soil analysis data revealed that the deficiencies of phosphorus (99\%) was widespread in Ethiopian soils [12].

Therefore, one of the strategies to improve bean yield on $\mathrm{P}$ deficient soils is application of adequate levels of $P$ fertilizers from external sources based on recommended rate for the crop. Consequently, in order to make site-specific recommendation of $\mathrm{P}$ for haricot bean production, nutrient rate experiment is needed. Therefore, this study was initiated with the objectives to determine yield response of haricot bean varieties to phosphorus fertilizer application on Andisolsat Hawassazuriya, Sidam Ethiopia.

\section{Materials and Methods}

\subsection{Description of Experimental Area}

This study was conducted on farmer field during 20182020 main cropping season at Hawassa zuriya, located between $6^{\circ} 57^{\prime} \mathrm{N}$ and $380^{\circ} 15^{\prime} \mathrm{E}$ to $70^{\circ} 10^{\prime} \mathrm{N}$ and $380^{\circ} 26^{\prime} \mathrm{E}$ Sidama Ethiopia and with altitude ranging from 1850 to 1934 meters above sea level. The mean annual rainfall ranges 800 $1100 \mathrm{~mm}$; the peak rainy months are July and August. The mean annual minimum and maximum temperatures are $12^{\circ} \mathrm{C}$ and $26.7^{\circ} \mathrm{C}$, respectively. The most dominant crops cultivated in the area are maize, and common bean. According to FAO, [13] the dominant soil type of the site is Andisols, and with textural class of silty loam.

\subsection{Treatments, Experimental Design and Procedure and Crop Management}

The treatments were factorial combinations of five $\mathrm{P}$ fertilizer rates $\left(0,10,20,30\right.$, and $\left.40 \mathrm{~kg} \mathrm{ha}^{-1}\right)$ and three varieties (Hawassa dume, Ibado and Nasir). The experiment was laid out as Randomized Complete Block Design (RCBD) in factorial combination with three replications. All rates of phosphorous (P) -TSP- fertilizer was once applied in band during planting. The starter nitrogen $(\mathrm{N})$ - UREA - was applied uniformly for all treatments. Furthermore, all necessary cultural and agronomic practices were carried out uniformly as per the recommendation for the crop at all stages of growth and development. The crop was harvested manually when $90 \%$ of the leaves and pods had turned yellow.

\subsection{Soil and Data Collection}

Pre-planting soil samples was taken randomly in a zigzag fashion from the experimental plots at the depth of $0-20 \mathrm{~cm}$ before planting. Then, the collected samples were air-dried at room temperature under shade and ground to pass through a 2 $\mathrm{mm}$ sieve for laboratory analysis of soil $\mathrm{pH}$, and available phosphorus. Small quantity of this $2 \mathrm{~mm}$ sieved soil material allowed to pass through $0.2 \mathrm{~mm}$ sieve for soil organic carbon and total nitrogen. The composite soil samples were analyzed for the selected physico-chemical properties such as, texture, $\mathrm{pH}$ total nitrogen $(\mathrm{N})$, available phosphorus $(\mathrm{P})$, available Sulphur (S), organic carbon (OC), cation exchange capacity (CEC), exchangeable potassium, magnesium and calcium using the standard soil laboratory procedures.

Crop data measuring like, plant height, number of pods plant $^{-1}$ and number of seeds pod, grain yield, total biomass and 1000 seed weight were recorded.

\subsection{Data Analysis}

Data from the field and laboratory were tested for normality, before being subjected to analysis of variance (ANOVA) using SAS software program version 9.4, [14]. The significant difference among treatment means was evaluated using the least significant difference at $(\mathrm{p} \leq 0.05)$. The analysis results of the soil and tissue samples were interpreted using descriptive statistics. Similarly, simple linear correlation analysis was carried out between crop growth parameters, yield, and yield components.

\subsection{Economic Analysis}

Economic analysis was performed using partial budget analysis following the procedure described by [15] in which prevailing market prices for inputs at planting and for outputs atharvesting were used. Average yield obtainedfrom experimental plot was reduced by $10 \%$ to adjust with the expected farmers yield by the same treatment. Prices of grain $\left(\mathrm{ETBkg}^{-1}\right)$ were obtained from local market for each variety: Hawassadume, Ibado and Nasir were 27, 13 and $9.5 \mathrm{ETB} \mathrm{kg}^{-1}$ respectively. Other costs such as cost of TSP and Urea fertilizer were 15.5 and $10.25 \mathrm{ETB} \mathrm{kg}^{-1}$ respectively.

\section{Results and Discussion}

\subsection{Soil Physico-Chemical Properties of Experimental Field}

The analysis results indicated that soil particle size distribution of the experimental site was in proportions of sand, silt and clay (39, 33 and 28\% respectively (Table 1). Based on FOA [13] soil textural classification the textural class of the soil of the sites were silt loam and clay respectively. The soil $\mathrm{pH}$ $\left(\mathrm{H}_{2} \mathrm{O}\right)$ analysis shows the $\mathrm{pH}$ value of the site was 6.75 which is neutral (Table 1). Tekalign [16] reported that when the soil $\mathrm{pH}$ ranges from 6.7-7.3 rates as neutral. Soil $\mathrm{pH}$ has a vital role in determining several chemical reactions and in influencing plant growth by affecting the activity of soil micro-organisms and altering the solubility and availability of most of the essential plant nutrients and particularly the micronutrients such as Fe, Zn, $\mathrm{B}, \mathrm{Cu}$ and $\mathrm{Mn}$ [17]. The analysis result show that available $\mathrm{P}$ 
content was $6.45 \mathrm{mg} \mathrm{kg}^{-1}$ (Table 1) which is rated as low according to [18]. The total nitrogen content of sites was 0.25 which is ranged at high level according to [16] classification. Similarly, organic carbon content was $3.31 \%$ which is ranged at high level according to [16] classification. The cation exchange capacity (CEC) of the soils were $25 \mathrm{Cmol}^{+} \mathrm{kg}^{-1}$ (Table 1). According to Hazelton, and Murphy [19] classification the experimental site soil was rated as moderate.

Table 1. Some soil physic-chemical properties of the experiment field before treatment application.

\begin{tabular}{ll}
\hline Parameters & Level \\
\hline Sand & $39 \%$ \\
Silt & $33 \%$ \\
Clay & $28 \%$ \\
Textural Class & Silt loam \\
pH ${ }_{2} \mathrm{O}(1: 2.5)$ & 6.75 \\
Available P $\left(\mathrm{mg} \mathrm{kg}^{-1}\right)$ & 6.45 \\
$\%$ Total Nitrogen & 0.25 \\
Organic Carbon \% & 3.31 \\
$\left.\mathrm{CEC}\left(\mathrm{cmol}^{+}\right) \mathrm{kg}^{-1}\right)$ & 25 \\
$\left.\mathrm{Ca}\left(\mathrm{cmol}^{+}\right) \mathrm{kg}^{-1}\right)$ & 7.01 \\
$\left.\mathrm{Mg}\left(\mathrm{cmol}^{+}\right) \mathrm{kg}^{-1}\right)$ & 0.48 \\
$\left.\mathrm{~K}\left(\mathrm{cmol}^{+}\right) \mathrm{kg}^{-1}\right)$ & 2.53 \\
$\left.\mathrm{Na}\left(\mathrm{cmol}^{+}\right) \mathrm{kg}^{-1}\right)$ & 5.35 \\
$\mathrm{Fe}\left(\mathrm{mg} \mathrm{kg}^{-1}\right)$ & 2.12 \\
$\mathrm{Mn}\left(\mathrm{mg} \mathrm{kg}^{-1}\right)$ & 3.33 \\
$\mathrm{Cu}\left(\mathrm{mg} \mathrm{kg}^{-1}\right)$ & 0.03 \\
$\mathrm{Zn}\left(\mathrm{mg} \mathrm{kg}^{-1}\right)$ & 0.61 \\
\hline
\end{tabular}

\subsection{Interaction Effects of Yield Components of Haricot Bean Varieties to Phosphorous Fertilizer}

Pulled mean analysis result revealed that application of different level of phosphorous fertilizer had significantly $(P<0.01)$ affects plant height, number of pods plant $^{-1}$ and number of seeds pod $^{-1}$ (Table 2).

Hawassa dume: The longest plant height $(55.5 \mathrm{~cm})$, maximum number of pods plant ${ }^{-1}(19.7)$ and number of seeds $\operatorname{pod}^{-1}$ (7.6) were obtained from application of $40 \mathrm{~kg}$ of $\mathrm{P} \mathrm{ha}^{-1}$. Whereas shortest plant, low number of pods plant $^{-1}$ and number of seeds pod ${ }^{-1}$ of Hawassadume variety was obtained from unfertilized or control plot (Table 2).

Ibado: Application of P fertilizer was significantly influenced growth and yield components of Ibado haricot bean variety. The longest plant height $(50.3 \mathrm{~cm})$, maximum number of pods plant ${ }^{-1}$
(9.4) and number of seeds pod $^{-1}$ (5.0) were obtained from application of $40 \mathrm{~kg}$ of $\mathrm{P} \mathrm{ha}^{-1}$. While, shortest plant, low number of pods plant ${ }^{-1}$ and number of seeds pod ${ }^{-1}$ were obtained from unfertilized or control plot (Table 2).

Nasir: Variety Nasir responds the highest plant height $(64.6 \mathrm{~cm})$, maximum number of pods plant $^{-1}$ (11.6) and number of seeds $\operatorname{pod}^{-1}$ (5.2) with application of $40 \mathrm{~kg}$ of $\mathrm{P} \mathrm{ha}$ 1 . While, shortest plant, low number of pods plant ${ }^{-1}$ and number of seeds pod $^{-1}$ were obtained from unfertilized or control plot (Table 2). This is because phosphorus is significantly affecting plant development, metabolism, flowering, fruiting and for adequate grain production and important in formation of strong root system [20,4].

In conformity with the current result, Moniruzzaman et al. [21] found that plant height was significantly increased up to application of phosphorus at the highest-level increased plant height. The increment of number of pods per plant due to application of $\mathrm{P}$ fertilizer confirms the fact that $\mathrm{P}$ fertilizer promotes the formation of nodes and pods in legumes. In agreement with this result, Dereje et al. [22] also found that the number of pods per plant of common bean significantly increased in response to increasing rate of phosphorus up-to the highest rate (40 $\mathrm{P} \mathrm{kg}_{5} \mathrm{ha}^{-1}$ ). Similarly, Shubhashree [23] reported that the number of seeds per pod of French bean increased significantly with the levels of phosphorus added.

The variation in the number of pods per plant among the varieties might be related to the genotypic variation of the cultivars in producing pods. In line with the results of the present study, different authors reported significant variations in the number of pods per plant for common bean varieties $[24,25]$. Consistent with the results of this study, Mourice and Tryphonne [25] observed significant variations in number of seeds per pod among common bean genotypes. The variation in number of seeds per pod could be attributed to the variation in the size of seeds of the cultivars; similarly, Ibado variety was large seed size and lower number of seeds per pod than Hawassa dume and Nasir.

In agreement with this result, Fageria and Santos [26] also reported that the number of seeds per pod of different common bean genotypes varied in the range of 3.1 to 6 and attributed the difference due to the genetic variation of cultivars.

Table 2. Pulled mean of plant height, number of pod plant ${ }^{-1}$ and number of seed pod ${ }^{-1}$ of haircoat bean as affected by phosphorous * variety interaction during 2018-2020 main cropping season.

\begin{tabular}{|c|c|c|c|c|c|c|c|c|c|c|c|c|c|c|c|}
\hline \multirow{3}{*}{ Variety } & \multicolumn{15}{|c|}{ Phosphorous $\left(\mathrm{kg} \mathrm{ha}^{-1}\right)$} \\
\hline & $\mathbf{0}$ & 10 & 20 & 30 & 40 & $\mathbf{0}$ & 10 & 20 & 30 & 40 & $\mathbf{0}$ & 10 & 20 & 30 & 40 \\
\hline & \multicolumn{5}{|c|}{ Plant height (cm) } & \multicolumn{5}{|c|}{ Number of pods plant $^{-1}$} & \multicolumn{5}{|c|}{ Number of seed pod ${ }^{-1}$} \\
\hline Hawass dume & $11.5^{\mathrm{j}}$ & $13.7^{\mathrm{ji}}$ & $19.9^{\mathrm{h}}$ & $38.7^{\mathrm{f}}$ & $55.5^{\mathrm{b}}$ & $5.5^{\text {gh }}$ & $9.7^{\mathrm{d}}$ & $12.5^{\mathrm{c}}$ & $15.6^{\mathrm{b}}$ & $19.7^{\mathrm{a}}$ & $2.2^{\mathrm{h}}$ & $2.7^{\mathrm{h}}$ & $4.1^{\mathrm{cd}}$ & $4.5^{\mathrm{c}}$ & $7.6^{\mathrm{a}}$ \\
\hline Ibbado & $13.6^{\mathrm{ji}}$ & $17.7^{\mathrm{hi}}$ & $20.3^{\mathrm{h}}$ & $30.5^{\mathrm{f}}$ & $50.3^{\mathrm{cd}}$ & $3.0^{\mathrm{i}}$ & $4.3^{\text {hi }}$ & $5.7^{\mathrm{gh}}$ & $9.0^{\mathrm{de}}$ & $9.4^{\mathrm{de}}$ & $2.4^{\mathrm{gh}}$ & $3.5^{\mathrm{ef}}$ & $3.9^{\mathrm{de}}$ & $4.0^{\mathrm{de}}$ & $5.0^{\mathrm{b}}$ \\
\hline Nasir & $39.0^{\mathrm{f}}$ & $43.9^{\mathrm{e}}$ & $47.5^{\mathrm{de}}$ & $53.9^{\mathrm{ab}}$ & $64.6^{\mathrm{a}}$ & 5.8 & $7.2^{\mathrm{fg}}$ & $8.1^{\mathrm{ef}}$ & $9.3^{\mathrm{de}}$ & $11.6^{\mathrm{c}}$ & $2.3^{\mathrm{h}}$ & $3.0^{\mathrm{fg}}$ & $3.8^{\mathrm{de}}$ & $4.0^{\text {cde }}$ & $5.2^{\mathrm{b}}$ \\
\hline $\mathrm{CV}$ & 12.9 & & & & & 16.5 & & & & & 12.7 & & & & \\
\hline Lsd $@ \leq 0.05$ & 4.2 & & & & & 1.6 & & & & & 0.5 & & & & \\
\hline Var*P & $* *$ & & & & & $*$ & & & & & $* *$ & & & & \\
\hline Var*year & $\mathrm{Ns}$ & & & & & $\mathrm{Ns}$ & & & & & $\mathrm{Ns}$ & & & & \\
\hline
\end{tabular}

Means in columns and rows followed by the same letters are not significantly different as judged by LSD test @ 5\% level ofsignificance. CV: Coefficient of variation. 


\subsection{Interaction Effects of Yields of Haricot Bean Varieties to Phosphorous Fertilizer}

Pulled mean analysis result showed that application of different level of phosphorous fertilizer had significantly $(\mathrm{P}<0.01)$ affects total above ground biomass, grain yield and 1000 seed weight (Table 3 ).

Hawassadume: The maximum total above ground biomass yield $\left(71.5 \mathrm{t} \mathrm{ha}^{-1}\right)$ grain yield $\left(25.64 \mathrm{t} \mathrm{ha}^{-1}\right)$ and 1000 seed weight (230.7 gm) of Hawassa dume was obtained from application of $40 \mathrm{~kg}$ of $\mathrm{P} \mathrm{ha}{ }^{-1}$. While, lowest, total above ground biomass yield $\left(11.6 \mathrm{t} \mathrm{ha}^{-1}\right)$ grain yield $\left(9.6 \mathrm{t} \mathrm{ha}^{-1}\right)$ and 1000 seed weight $(114.8 \mathrm{gm})$ of Hawassa dume was obtained from unfertilized or control plot (Table 3 ).

Ibado: Application of $\mathrm{P}$ fertilizer significantly influenced growth and yield components of Ibado haricot bean variety. The maximum total above ground biomass yield $\left(47.3 \mathrm{t} \mathrm{ha}^{-1}\right)$ grain yield $\left(22.4 \mathrm{t} \mathrm{ha}^{-1}\right)$ and 1000 seed weight (266.6 gm) were obtained from application of $40 \mathrm{~kg}$ of $\mathrm{P} \mathrm{ha}^{-1}$ (Table 3).

Nasir: Increasing the level of $P$ fertilizer was also increase the yield of Nasir haircoat bean variety. The maximum total above ground biomass yield $\left(56.1 \mathrm{t} \mathrm{ha}^{-1}\right)$ grain yield $(21.1 \mathrm{t}$ $\left.\mathrm{ha}^{-1}\right)$ and 1000 seed weight $(207.4 \mathrm{gm})$ were obtained from application of $40 \mathrm{~kg}$ of $\mathrm{P} \mathrm{ha}{ }^{-1}$. were obtained from unfertilized or control plot (Table 3).

This result was in line with Amare et al. [27] were reported that above ground biomass and grain yields of haircoat bean varieties of Hawassaduume, Ibbado and Nasir were significantly increased with increasing P fertilizer level. Similarly, Amare et al. [27] observed significant increase in thousand seed weights of common bean as a result of phosphorus application up to 40 $\mathrm{kg} \mathrm{ha}^{-1}$. Variation in hundred seed weight might have occurred due to the presence of difference in seed size among the common bean varieties as hundred seed weight increases with increase in the seed size. However, the higher 1000 seed weight for variety Ibado is associated with the size of the seed; in accordance with Hawtin et al. [28] who explained that the larger the seed, the higher its seed weight. The increase in hundred seed weight as a result of increased $\mathrm{P}$ application might be attributed to important roles the nutrient plays in regenerative growth of the crop [29] leading to increased seed size which in turn may improve hundred seed weight [30].

Differences in seed yield among the common bean varieties might be related to the genotypic variations in $\mathrm{P}$ use efficiency Hence, the cultivars which produced higher grain yield might have either better ability to absorb the applied $\mathrm{P}$ from the soil solution or translocate and use the absorbed $\mathrm{P}$ for grain formation than the low yielding cultivar. In agreement with the results of this study, [31, 25] observed significant variations in grain yield for common bean due to genotypic variations for $\mathrm{P}$ use efficiency which may arise from variation in $\mathrm{P}$ acquisition and translocation and use of absorbed $\mathrm{P}$ for grain formation in common bean.

Table 3. Pulled mean of above ground biomass, grain yield and 1000 seed weight of haircoat bean as affected by phosphorous * variety interaction during 2018-2020 main cropping season.

\begin{tabular}{|c|c|c|c|c|c|c|c|c|c|c|c|c|c|c|c|}
\hline \multirow{3}{*}{ Variety } & \multicolumn{15}{|c|}{ Phosphorous (kg ha $\left.{ }^{-1}\right)$} \\
\hline & $\mathbf{0}$ & 10 & 20 & 30 & 40 & $\mathbf{0}$ & 10 & 20 & 30 & 40 & $\mathbf{0}$ & 10 & 20 & 30 & 40 \\
\hline & \multicolumn{5}{|c|}{ Above ground biomass $\left(\mathrm{t} \mathrm{ha}^{-1}\right)$} & \multicolumn{5}{|c|}{ Grain yield (t ha $\left.{ }^{-1}\right)$} & \multicolumn{5}{|c|}{1000 seed weight (gm) } \\
\hline Hawass dume & $11.4^{\mathrm{i}}$ & $20.6^{\text {gh }}$ & $31.9^{\mathrm{f}}$ & $51.6^{\mathrm{c}}$ & 71.5 & $9.6^{\mathrm{i}}$ & $15.5^{\mathrm{ef}}$ & $19.7^{\mathrm{c}}$ & $21.2^{\mathrm{bc}}$ & $25.64^{\mathrm{a}}$ & $114.8^{\mathrm{i}}$ & $144.1^{\text {gh }}$ & $152.3^{\mathrm{fg}}$ & $181.1^{\mathrm{e}}$ & $230.7^{\mathrm{a}}$ \\
\hline Ibbado & $13.1^{\mathrm{i}}$ & $19.1^{\mathrm{h}}$ & $29.1^{\mathrm{f}}$ & $39.1^{\mathrm{e}}$ & $47.3^{\mathrm{d}}$ & $10.1^{\mathrm{i}}$ & $13.1^{\mathrm{gh}}$ & $17.1^{\mathrm{de}}$ & $21.3^{\mathrm{bc}}$ & $22.4^{\mathrm{b}}$ & $112.7^{\mathrm{i}}$ & $159.1^{\mathrm{f}}$ & $195.9^{d}$ & $219.9^{\mathrm{bc}}$ & $266.6^{\mathrm{b}}$ \\
\hline Nasir & $17.1^{\mathrm{h}}$ & $22.0^{\mathrm{g}}$ & $29.1^{\mathrm{f}}$ & $37.1^{\mathrm{e}}$ & $56.1^{\mathrm{b}}$ & 11.1 & $14.4^{\mathrm{fg}}$ & $17.9^{\mathrm{e}}$ & $19.1^{\mathrm{cd}}$ & $21.1^{\mathrm{bc}}$ & $108.9^{\mathrm{i}}$ & $130.6^{\mathrm{h}}$ & $143.5^{\mathrm{gh}}$ & $164.2^{f}$ & $207.4^{\mathrm{cd}}$ \\
\hline $\mathrm{CV}$ & 16.2 & & & & & 12.5 & & & & & 8.2 & & & & \\
\hline $\operatorname{Lsd} @ \leq 0.05$ & 373.6 & & & & & 218.7 & & & & & 14.2 & & & & \\
\hline Var*year & Ns & & & & & Ns & & & & & Ns & & & & \\
\hline
\end{tabular}

Means in columns and rows followed by the same letters are not significantly different as judged by LSD test at $5 \%$ level of significance. CV: Coefficient of variation.

\subsection{Economic Analysis}

Economic results showed that all treatments were economically feasible as the net benefit values (NBV) were greater than zero $(\mathrm{NBV}>0)$ (Table 4). The maximum (63157.8 Et-birr ha ${ }^{-1}$ ) and minimum (22696.2 Et- birr ha ${ }^{-1}$ ) NBV for Hawassadume were obtained from application of 40 $\mathrm{P} \mathrm{kg} \mathrm{ha}{ }^{-1}$ and unfertilized plot or control. The maximum (24342.2 Et-birr ha ${ }^{-1}$ ) and minimum (12446.2 Et- birr ha ${ }^{-1}$ )
NBV for Ibado were obtained from application of $40 \mathrm{P} \mathrm{kg} \mathrm{ha}$ 1 and unfertilized plot or control. Similarly, the maximum (15124.9 Et-birr ha $^{-1}$ ) and minimum (9792.6 Et- birr ha ${ }^{-1}$ ) NBV for Nasir were obtained from application of $40 \mathrm{P} \mathrm{kg} \mathrm{ha}$ 1 and unfertilized plot or control (Table 4). Finally, Hawassadume was found to be the most productive cultivar for economical production in the study areas.

Table 4. Effects of the phosphorous fertilizers on economic profitability of haircoat beanvarieties.

\begin{tabular}{|c|c|c|c|c|c|c|}
\hline Variety & $P\left(\mathrm{~kg} \mathrm{ha}^{-1}\right)$ & $\operatorname{AGY}\left(\mathrm{kg} \mathrm{ha}^{-1}\right)$ & GBV (ETB kg ha-1) & TVC (ETB) & NBV (ETB kg ha-1) & MRR\% \\
\hline \multirow{5}{*}{ Hawass dume } & 0 & 915.6 & 24721.2 & 2025 & 22696.2 & - \\
\hline & 10 & 1547.5 & 41782.5 & 3354 & 38428.5 & 1184 \\
\hline & 20 & 1970.2 & 53195.4 & 4254 & 48941.4 & 1168 \\
\hline & 30 & 2095.2 & 56570.4 & 5154 & 51416.4 & 275 \\
\hline & 40 & 2563.4 & 69211.8 & 6054 & 63157.8 & 1305 \\
\hline
\end{tabular}




\begin{tabular}{|c|c|c|c|c|c|c|}
\hline Variety & $P\left(\mathrm{~kg} \mathrm{ha}^{-1}\right)$ & $\operatorname{AGY}\left(\mathrm{kg} \mathrm{ha}^{-1}\right)$ & GBV (ETB kg ha $\left.{ }^{-1}\right)$ & TVC (ETB) & NBV (ETB kg ha-1) & MRR\% \\
\hline \multirow{5}{*}{ Ibado } & 0 & 1032.4 & 13421.2 & 975 & 12446.2 & - \\
\hline & 10 & 1265.4 & 16450.2 & 2304 & 14146.2 & 128 \\
\hline & 20 & 1730.6 & 22497.8 & 3204 & 19293.8 & 572 \\
\hline & 30 & 2125.5 & 27631.5 & 4104 & 23527.5 & 470 \\
\hline & 40 & 2257.4 & 29346.2 & 5004 & 24342.2 & 91 \\
\hline \multirow{5}{*}{ Nasir } & 0 & 1105.8 & 10505.1 & 712.5 & 9792.6 & - \\
\hline & 10 & 1373.8 & 13051.1 & 2041.5 & 11009.6 & 92 \\
\hline & 20 & 1687.5 & 16031.3 & 2941.5 & 13089.8 & 231 \\
\hline & 30 & 1921.1 & 18250.5 & 3841.5 & 14409 & 147 \\
\hline & 40 & 2091.2 & 19866.4 & 4741.5 & 15124.9 & 80 \\
\hline
\end{tabular}

Where, ETB=Ethiopian Birr (currency); AGY=adjusted grain yield, GBV=growth benefit value, TCV=Total variable cost; NBV=Net benefit value; MRR=Marginal rate of return; Price for phosphorus Fertilizer $=15.50$ ETB kg-1, Price for haircoat bean cultivars Hawassadume $=27$ ETB kg ${ }^{-1}$, Ibado $=13$ ETB $\mathrm{kg}^{-1}$ andNasir $=9.5 \mathrm{ETB} \mathrm{kg}^{-1}$.

\section{Conclusions and Recommendation}

Based on the study the result that the maximum grain yield of Hawassadume $\left(25.6 \mathrm{t} \mathrm{ha}^{-1}\right)$, Ibbado $\left(22.4 \mathrm{t} \mathrm{ha}^{-1}\right)$ and Nasir $\left(21.1 \mathrm{t} \mathrm{ha}^{-1}\right)$ were obtained from application of $40 \mathrm{~kg} \mathrm{P} \mathrm{ha}{ }^{-1}$. Hawassa dume variety showed the best performance followed almost in all measured parameters followed by Nasir where as Ibbado showed the least except in 1000seed weight. According, to results suggested that all treatments were economically feasible as the net benefit values (NBV) were greater than zero $(\mathrm{NBV}>0)$. But Hawassadume was found to be the most productive cultivar for economical production in the study areas. These results revealed the benefit of phosphorus fertilizer application and variety consideration for yield improvement, of common in the study area. Thus, based on the result obtained, it was possible to conclude that phosphorus fertilizer rate of $40 \mathrm{~kg} \mathrm{Pha}^{-1}$ was promising to enhance yield of haricot bean on each variety at Hawassa Sidama, Ethiopia and similar areas which have the same soil property.

\section{Conflicts of Interest}

The authors declare no conflict of interest.

\section{Acknowledgements}

The authors gratefully acknowledge Wondo Genet Agricultural Research Center and members of the natural resource management process, during experimentation work. This study was fully supported by Ethiopian Institute of Agricultural Research (EIAR).

\section{References}

[1] CSA (Central Statistical Agency). 2016. Agricultural Sample Surveys. CSA, Addis Ababa, Ethiopia.

[2] Mamo, T. and Haque I., 1991. Phosphorus status of some Ethiopian soils. II, Forms and distribution of inorganic phosphates and their relation to available phosphorus. Trop. Agric., 68: 2-8.
[3] Van Schoonhoven T, Voysest H (1991) Common bean: Research for Crop Improvement, CIAT, Cali, Colombia.

[4] Havlin, J. L., J. D. Beaton, S. L. Tisdale, and W. L. Nelson. 1999. Soil Fertility and Fertilizers: An Introduction to Nutrient Management. 6th ed. Upper Saddle River, N. J.: Prentice Hall.

[5] Mengel, K. and E. A. Kirkby, 2001. Principles of Plant Nutrition. $5^{\text {th }}$ Edn., Kluwer Academic Publishers, Dordrecht/Boston/London, ISBN-13: 9781402000089, Pages: 849.

[6] Halvorson, A. D., and A. L. Black. 1985. Long term dryland crop responses to residual phosphorus fertilizer. Soil Sci. Soc. Am. J. 49: 928-933.

[7] Barbosa Filho MP, Silva OF. 1994. Aspectos agroeconomicos da calagem e da adubacaonasculturas de arrozefeijaoirrigadosporaspersao. Pes Agro Bras 29, 16571667. (with English abstract).

[8] Singh, S. P., 1982. A key for identification of different growth habits of Phaseolusvulagris L. New York Ann. Rep. Bean Improv. Coop, Program, 25: 92-95.

[9] Gidago, G., S. Beyene and W. Worku, 2011. The response of haricot bean (Phaseolus vulgaris L.) to phosphorus application on Ultisols at Areka, Southern Ethiopia. J. Biol. Agric. And Healthcare, 1: 38-49.

[10] Fageria NK, de CarvalhoAM. 1996. Response of common bean to phosphorus on acid soils. Comm. Soil Sci. Plant Analy. $27,1447-1458$.

[11] Banerjee S, Palit R, Sengupta C, Standing D. 2010. Stress induced phosphate solubilization by Arthrobacter sp. and Bacillus sp. isolated from tomato rhizosphere. Aust J Crop Sci 1 (6), 378-383.

[12] Ethio-SIS (Ethiopian Soil Information System). 2016. Soil Analysis Report. Agricultural Transformation Agency (Unpublished).

[13] FAO (Food and Agriculture Organization). 2014. World Reference Base for Soil Resources International soil classification system for naming soils and creating legends for soil maps. World Soil Resources Reports No. 106. Food and Agriculture Organization of the United Nations (FAO), Rome, Italy.

[14] SAS (Statistical Analysis System Institute). 2014. SAS Version 9.4 (C) 2002-2012. SAS Institute, Inc., Cary, North Carolina, USA. 
[15] CIMMYT (The International Maize and Wheat Improvement Center). 1988. From Agronomic Data to farmer Recommendations. An economic Training Manual completely revised edition. Mexico, D. F.

[16] Tekalign Tadese. 1991. Soil, plant, water, fertilizer, animal manure and compost analysis. Working Document No. 13. International Livestock Research Center for Africa, Addis Ababa, Ethiopia.

[17] Sumner, M. E. 2000. Handbook of Soil Science, CRC Press, Boca Raton, FL.

[18] Cottenie A. 1980. Soil and plant testing as a basis of fertilizer recommendations. FAO soil bulletin.

[19] Hazelton, P., and B. Murphy, 2007. Interpreting soil test results: What do all the numbers mean $2^{\text {nd }}$ Edition. CSIRO Publishing. 152p.

[20] Brady, N. C and Weil R. R. 2002. The nature and properties of Soils. Thirteenth edition, Prentice Hall, New Jersey, 960 p.

[21] Moniruzzaman M, Islam MR, Hasan J. 2008. Effect of N, P, K, $\mathrm{S}, \mathrm{Zn}$, and $\mathrm{B}$ on yield attributes and yield of French bean in south eastern hilly region of Bangladesh. Journal of Agriculture and Rural Development 6 (1\& 2): 75-82.

[22] Dereje SND, Setegn G. 2015. Response of common bean cultivars to phosphorus application in SodoZuria Districts, Southern Ethiopia. East African Journal of Sciences 9 (1): 4960 .

[23] Shubhashree KS. 2007. Response of Rajmash (Phaseolus vulgaris L.) to the Levels of Nitrogen, Phosphorus and Potassium during Rabi in the Northern Transition Zone. MSc Thesis, Dharwad University of Agricultural Science, Dharwad.
[24] Fageria NK, Baligar VC, Moreira A, Portes TA. 2010. Dry bean genotypes evaluation for growth, yield component and phosphorus use efficiency. Journal of Plant Nutrition 33 (14): 2167-2181.

[25] Mourice SK, Tryphone GM. 2012. Evaluation of common bean (Phaseolus vulgaris L.) genotypes for adaptation to low phosphorus. International Scholarly Research Network Agronomy. 2012: 1-9.

[26] Fageria NK, Santos AB. 2008. Yield physiology of dry bean. Journal of Plant Nutrition 31: 983-1004.

[27] Amare G, Assaye D, Tuma A 2014. The response of haricot bean varieties to different rates of phosphorus at Arba-Minch, Southern Ethiopia. ARPN Journal of Agricultural and Biological Science 9 (10): 344-350.

[28] Hawtin G. C., K. B. Singh, and M. C. Saxena. 1980. Some recent development in the understanding and improvement of Cicer and Lens. pp. 613-623. In: R. J.

[29] Zafar M, Abbasi MK, Khaliq A. 2013. Effect of different phosphorus sources on the growth, yield, energy content and phosphorus utilization efficiency in maize at Rawalako Azad Jammu and Kashmir, Pakistan. Journal of Plant Nutrition 36: 1915-1934.

[30] Fageria NK. 2009. The Use of Nutrients in Crop Plants. CRC Press, Boca Raton, FL. Available at: Plants. /Fageria/p/book/9781420075106.

[31] Gobeze L, Legese H. 2015. Evaluation of common bean varieties at phosphorus deficient and sufficient condition in southern Ethiopia. AshEse Journal of Agricultural Sciences 1 (4): 020-027. http://www.ashese.co.uk/agriculturalscience/blog. 